\title{
Analysis Of The Effect Of Self Gratification, Aesthetics, Price, Prestige, Transaction, Hedonic And Quality Dimensions On Customer Loyalty Through Customer Satisfaction On Vasa Hotel Customers In Surabaya
}

\author{
Axcell Reinhart Bill Angriawan, Ronald ${ }^{\mathrm{b}}$, Amelia $^{\mathrm{c} *}$ \\ axcell1602@gmail.com \\ ${ }^{a}$ Master of Management Student at Pelita Harapan University, Surabaya 60234, Indonesia \\ ${ }^{b, c}$ The Lecturer of Master of Management at Pelita Harapan University, Surabaya 60234, Indonesia
}

\begin{abstract}
Hotels are the need for accommodation facilities that provide lodging facilities and services, food, drinking and other services for the public. This study aims to determine how the influence of Self Gratification, Aesthetics, Price, Prestige Transaction, and Quality on Customer Loyalty through Customer Satisfaction. The expected benefit from this research is to increase knowledge in the field of management, especially how much influence Customer Satisfaction will have, thereby increasing Customer Loyalty which in turn will increase actual return visits from the Vasa Hotel company in Surabaya. This study is causal. The method used is quantitative methods of processing the data using AMOS. Data was collected by distributing questionnaires to 175 respondents with the characteristics of male and female respondents aged 18-60 years, know about Vasa Hotel and come from Vasa Hotel at least 2 times in 2 years and live in Surabaya. Based on the regression results, from the 15 proposed hypotheses, 12 hypotheses were accepted and 3 hypotheses were rejected. The accepted hypothesis includes: the effect of Self Gratification, Aesthetics, Price, Prestige, Transaction, Hedonic, Quality has a significant effect on Customer Satisfaction with a value of C.R. is above 2.00. Furthermore, the influence of Aesthetics, Price, Prestige, Quality, Customer Satisfaction has a significant effect on Customer Loyalty with a value of C.R. is above 2.00
\end{abstract}

Keywords: Self Gratification, Aesthetics, Price, Prestige, Transaction, Hedonic, Quality, Customer Satisfaction, Customer Loyalty.

\section{Introduction}

The hotel is a commercially managed building providing lodging facilities for the public with service facilities. A hotel is a building with rooms that are rented out as a place to stay and eat for on-the-go people, or a commercially managed form of accommodation. Hotels are the need for accommodation facilities that provide lodging facilities and services, food, drinking and other services for the public. In addition, the hotel is a service business in which there are elements of service, comfort, and lodging facilities needed for consumers who need lodging facilities for the benefit of their families and vacations. (https://salamadian.com/, downloaded on February 5, 2020)

Over time and changing lifestyles, the function of the hotel has changed a lot. Not only a place to stay and have a vacation, but also a hotel at this time is a place to hold various activities, including to hold meetings, meetings, weddings, seminars, and many things that can be done in hotels. Apart from the usefulness of the hotel itself, the function of the hotel can also be seen from the needy side or depending on 
the different perspectives of each individual. Among them, when viewed from the side of the hotel owner, the hotel functions to get financial benefits. When viewed from the employee's point of view, hotels are a place to make a living. When viewed from the guest side, the hotel functions as a temporary place to stay for a vacation and when viewed from the government side, the hotel serves to increase regional income and can help promote local tourist attractions. (https://salamadian.com/, downloaded on February 5, 2020)

Business development in Indonesia has increased due to economic globalization which has increasingly opened up opportunities for foreign entrepreneurs to invest in Indonesia and attract local customers. The impact of globalization has caused companies in the service sector to develop rapidly, followed by the growth in the number of accommodation businesses in Indonesia. At this time, the development of the hotel industry is growing rapidly. Along with the development of industrial technology, economy, and tourism business, according to data set by the ministry of tourism or usually referred to as KEMENPAR, it shows that Indonesia is one of the countries that sells a variety of destinations or destinations and directions. The variety of destinations in Indonesia makes people need hospitality services. Therefore, hotels are an important role in increasing the tourism sector. The increase in the tourism sector makes the hotel industry continue to grow and improve the economy in Indonesia. (https: // http://www.kemenparekraf.go.id//, downloaded on 30 November 2015)

Hotel Vasa Surabaya is one of the businesses engaged in the service sector, namely hospitality. This hotel was established in November 2016. Hotel Vasa is one of the most luxurious five-star hotels in the West Surabaya area. Hotel Vasa is a local-based hotel with wisdom that is not inferior to other foreign star hotels. Hotel Vasa itself is located in the heart of the city near the main road which is easily accessible from prestigious office locations in Surabaya, historical places, upscale shopping, restaurants and nightlife. (https: // http: // www.vasahotelsurabaya.com//)

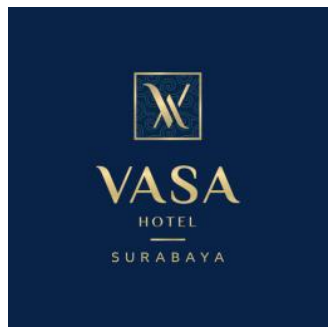

Figure 1.1 Vasa Hotel Logo

Hotel Vasa provides exceptional design, Hotel Vasa offers 383 rooms consisting of suites, and Vasa Residences combines the privacy and comfort of a private apartment with the services and facilities of a world-class luxury hotel. Hotel Vasa offers room accommodation that is more spacious than standard hotel rooms in Surabaya and is suitable for both short and long term stays. Hotel Vasa Surabaya also has 7 meeting rooms and a Grand Ballroom that can accommodate up to 2000 people. Of course, all of these rooms are equipped with modern facilities that are suitable for you to hold events such as corporate meetings, gatherings, birthday celebrations to weddings. (http: // www.harpersbazaar.co.id//, downloaded on 5 October 2018). 
Figure 1.2 Brazilian Curasscaria Chamas

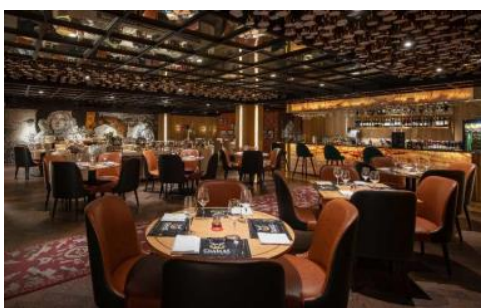

The facilities provided by the Vasa Hotel are very many and of high quality. Besides the adequate and complete rooms and rooms, Hotel Vasa provides various types of culinary which can be served by the team from Hotel Vasa itself. Among them are 209 Dinning which serves a variety of traditional to international dishes. Next Hotel Vasa provides Chinese and Cantonese specialties such as Yin Yang's Xiao Long Pao, Pan Seared Ocean King Prawn with Lemon Chili Champagne Sauce and various Dim Sum at Xiang Fu Hai Cuisine. In addition, Hotel Vasa will also open a restaurant with Brazilian dishes called Chamas Brazilian Churrascaria. (http: // www.harpersbazaar.co.id//, downloaded on 5 October 2018).

Hotel Vasa also provides a place for body fitness at Flex \& Fit, a gym facility equipped with complete equipment. Hotel Vasa also has an outdoor swimming pool with panoramic views of the city of Surabaya. Hotel Vasa provides a playground for children, namely the Indoor Kids Playground. Hotel Vasa also has an Executive Lounge for customers who want a more personal service. And also one of the advantages possessed by Vasa Hotel is the existence of international bestandart helipad facilities which are specifically intended for hotel guests who stay overnight. This helipad can help business people and executives who need fast mobility to and from the hotel. (http://www.kabarbisnis.com///, downloaded on 7 November 2016).

Recently the Vasa Hotel was established, Hotel Vasa has won several awards such as Hotel Vasa won the Traveloka Hotel Awards in 2018 which gives appreciation to the national and international hotel industry and awards hotel partners who have positive reviews throughout 2017 which are included in four aspect categories, namely food, cleanliness, service, and overall. Traveloka Hotel Awards 2018 also uses consumer reviews as the basis for selecting winners. The Best Service category is divided into 3 parts, namely Value, Premium and Prestige. Hotel Vasa as a five star hotel under the management of Tanly Hospitality which represents East Java which competes at national and international levels. (http://www.beritajatim.com//, downloaded on 23 October 2018).

Hotel Vasa received another award from the Agoda 2018 Gold Circle Awards which was received on 3 December 2018. Agoda gives appreciation to the national and international hospitality industry as well as awards to hotel partners who are committed to providing the best prices, choices and best experiences. In addition, service, quality and value are the main assessments. In the assessment that has been carried out, Vasa Hotel Surabaya has received 8.7 points based on the shopping site and Agoda hotel reviews. (http://www.otoplasa.com//, downloaded December 2018).

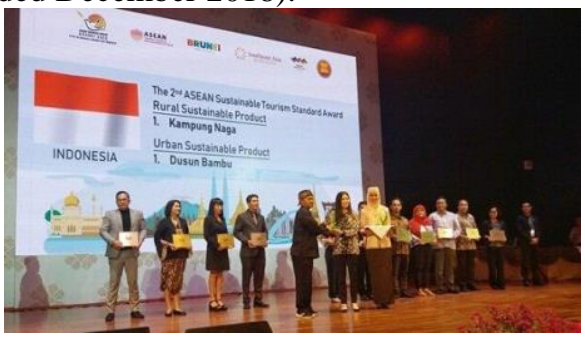

Figure 1.3 ASEAN Tourism Awards 2019 
And also Hotel Vasa Surabaya received an award in January 2019, namely the Vasa Hotel being one of the recipients of the 2019 ASEAN MICE Venue Standard award. This category was nominated in the award recipient at the ASEAN Tourism Forum 2020 which is one of the most prestigious awards for tourism industry players in all regions. -Southeast Asia. As a five-star hotel that has a total of 7 meeting rooms and 1 grand ballroom coupled with complete equipment and experienced staff, the ASEAN Tourism Forum 2020 gave an award to Vasa Hotel Surabaya as a hotel that organizes MICE (Meeting, Incentive, Convention, and Exhibition) with Asian standards. Southeast after going through the various stages shown in Figure 1.3 (http: // www. Inforial.tempo.com//, can be downloaded on February 6, 2020).

\section{Litterature Review}

\subsection{Theories and Hypotheses}

\subsubsection{Self-Gratification}

Venkatesh (2000) explains that Self Gratification is perceived enjoyment as the extent to which activities using a particular system are considered pleasurable in itself, apart from the performance consequences resulting from using the system. According to Jung \& Yoon (2010) found that Self-Gratification has a significant positive effect on Customer Satisfaction. In other words, when one feels pleasure in coming to create a feeling of satisfaction too. According to Setiyorini et al., (2019) found that Self-Gratification has a significant positive effect on Customer Loyalty.

H1: Self Gratification has a significant effect on Customer Satisfaction

H8: Self Gratification has a significant effect on Customer Loyalty

\subsubsection{Aesthetics}

According to Kotler and Keller (2012), aesthetics is beauty that shows how the product looks or attracts buyers. For example, the physical form of an attractive shop, artistic models or designs, colors, and so on. Zhang, D (2010) found that there is a positive and significant influence between Aesthetics on Customer Satisfaction. According to Gallarza et al., (2016) found that Aesthetics has a significant positive effect on Customer Loyalty.

H2: Aesthetics has a significant effect on Customer Satisfaction

H9: Aesthetics has a significant effect on Customer Loyalty

\subsubsection{Price}

According to Kotler (2008), price is the sum of all values provided by customers for benefits, possessions, use of products or services. According to Eid, R. (2015) found that Price has a significant positive effect on Customer Satisfaction. According to Setiyorini et al., (2019) found that Price has a significant positive effect on Customer Loyalty.

H3: Price has a significant effect on Customer Satisfaction

H10: Price has a significant effect on Customer Loyalty

\subsubsection{Prestige}

According to Chepchirchir \& Leting (2015), prestige is an expression of evaluative judgment that conveys a high or low status that depends on life experience, knowledge and awareness of competitors' brands. According to Jin et al., (2016) found that Prestige has a significant positive effect on Customer Satisfaction. According to Setiyorini et al., (2019) found that Prestige has a significant positive effect on Customer Loyalty.

H4: Prestige has a significant effect on Customer Satisfaction

H11: Prestige has a significant effect on Customer Loyalty 


\subsubsection{Transaction}

According to Davis et al., (2015) Transaction Value is defined as the joy obtained when getting a good offer. According to Lai et al., (2013) found that Transaction has a significant positive effect on Customer Satisfaction. According to Setiyorini et al., (2019) found that Transaction has a significant positive effect on Customer Loyalty.

H5: Transaction has a significant effect on Customer Satisfaction

H12: Transaction has a significant effect on Customer Loyalty

\subsubsection{Hedonic}

Hedonic is the emotional benefits, pleasure, and satisfaction generated by pleasure from the shopping experience (Bellenger et al., 1976). Likewise according to Hirschman, (1983) emotional arousal, high involvement, perceived freedom, and realization of fantasy and escape all symbolize the hedonic value of shopping. According to Lee \& Kim (2018), Hedonic has a significant positive effect on Customer Satisfaction. Furthermore, according to Lee \& Kim (2018), Hedonic has a significant positive effect on Customer Loyalty.

H6: Hedonic has a significant effect on Customer Satisfaction

H13: Hedonic has a significant effect on Customer Loyalty

\subsubsection{Quality}

According to Sweeney \& Soutar (2014), quality value in hotels is utility that comes from the reliability and excellence of service performance. Quality is a dynamic condition that affects products, services, people, processes and the environment that meet or exceed expectations (Tjiptono, 2014). According to Deng et al., (2013) found that Quality has a significant positive effect on Customer Satisfaction. According to Eid, R. (2015) found that Quality has a significant positive effect on Customer Loyalty.

\section{H7: Quality has a significant effect on Customer Satisfaction}

H14: Quality has a significant effect on Customer Loyalty

\subsubsection{Customer Satisfaction}

Kotler (2012) states that customer satisfaction can be considered as perceptual knowledge through perceptions of the results perceived by individuals in their expectations. According to Eid, R. (2015) found that customer satisfaction has a significant positive effect on customer loyalty. According to Liu et al., (2017) found that customer satisfaction has a significant positive effect on customer loyalty.

\section{H15: Customer Satisfaction has a significant effect on Customer Loyalty}

\subsubsection{Customer loyalty}

According to Dehghan and Shahin (2011) Customer loyalty is a positive action that consumers can show to brands, shops, products and activities. Meanwhile, according to Fernandes (2017) Loyalty can be defined as a firmly held commitment by consumers to consistently repurchase preferred products or services in the future, even though the situational influence and marketing efforts of other companies have the potential to cause behavioral shifts. 


\subsection{Research Model}

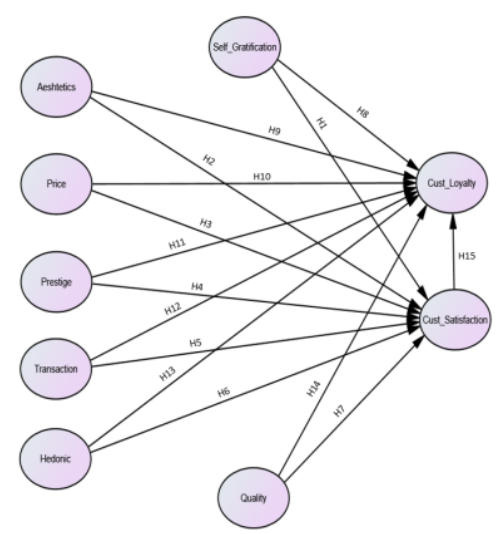

Figure 2.1: The Framework of Research Model

\section{Research Methods}

The research method

The method used in this research is quantitative method. In this study, the research population is consumers who have visited and directly used the services of "Vasa Hotel" in Surabaya. In this study, the method used to take samples is non-probability sampling and snowball sampling and to collect data using a questionnaire method. The non-probability sampling method is used because the population who has used the application from Shopee is not known for sure. Meanwhile, snowball is used so that the distribution of questionnaires can be done quickly and precisely. To distribute questionnaires using the snowball method, I distributed them to friends at UPH Surabaya campus and later friends would help distribute the questionnaires to other people. In accordance with the determined characteristics, by having certain characteristics, namely: (1) Male and Female; (2) Domiciled in the Surabaya area; (3) 18-60 years old; (4) Have stayed directly at Hotel Vasa at least 2 times in the last 2 years. Furthermore, the metabulation of the respondents' research results will be tested by using the Amos software

\section{Results and Discussion}

\subsection{Assessment of Measurement Model}

Table 4.1: Regression Weights Full Structural Equation Model

\begin{tabular}{|lrl|rrrrc|}
\hline & & & Estimate & S.E. & C.R. & P & $\begin{array}{c}\text { Std. } \\
\text { Estimate }\end{array}$ \\
\hline Customer_Satisfaction & $<---$ & Prestige & .174 & .084 & 2.074 & .038 & .175 \\
Customer_Satisfaction & $<---$ & Transaction & .335 & .084 & 4.004 & $* * *$ & .327 \\
Customer_Satisfaction & $<---$ & Hedonic & .338 & .086 & 3.949 & $* * *$ & .337 \\
Customer_Satisfaction & $<---$ & Quality & .340 & .092 & 3.687 & $* * *$ & .297 \\
Customer_Satisfaction & $<---$ & Price & .211 & .080 & 2.637 & .008 & .225 \\
Customer_Satisfaction & $<---$ & Aeshtetics & .237 & .073 & 3.241 & .001 & .275 \\
Customer_Satisfaction & $<---$ & Self_Gratification & .175 & .082 & 2.142 & .032 & .170 \\
Customer_Loyalty & $<---$ & Prestige & .127 & .060 & 2.126 & .034 & .172 \\
\hline
\end{tabular}




\begin{tabular}{|c|c|c|c|c|c|c|c|}
\hline & & & Estimate & S.E. & C.R. & $\mathrm{P}$ & $\begin{array}{c}\text { Std. } \\
\text { Estimate }\end{array}$ \\
\hline Customer_Loyalty & $<---$ & Transaction & .082 & .069 & 1.179 & .238 & .107 \\
\hline Customer_Loyalty & $<---$ & Hedonic & .072 & .069 & 1.040 & .298 & .097 \\
\hline Customer_Loyalty & $<---$ & Quality & .224 & .077 & 2.909 & .004 & .263 \\
\hline Customer_Loyalty & $<---$ & Price & .175 & .060 & 2.907 & .004 & .250 \\
\hline Customer_Loyalty & $<---$ & Aeshtetics & .122 & .059 & 2.093 & .036 & .191 \\
\hline Customer_Loyalty & $<---$ & Self_Gratification & .012 & .055 & .213 & .831 & .015 \\
\hline Customer_Loyalty & $<---$ & Customer_Satisfaction & .265 & .125 & 2.115 & .034 & .356 \\
\hline $\mathrm{X} 3$ & $<---$ & Self_Gratification & 1.000 & & & & .786 \\
\hline $\mathrm{X} 2$ & $<---$ & Self_Gratification & .753 & .099 & 7.647 & $* * *$ & .615 \\
\hline $\mathrm{X} 1$ & $<---$ & Self_Gratification & .948 & .102 & 9.290 & $* * *$ & .751 \\
\hline $\mathrm{X} 7$ & $<---$ & Aeshtetics & 1.000 & & & & .816 \\
\hline X6 & $<---$ & Aeshtetics & .755 & .098 & 7.729 & $* * *$ & .669 \\
\hline $\mathrm{X} 5$ & $<---$ & Aeshtetics & .783 & .101 & 7.728 & $* * *$ & .638 \\
\hline $\mathrm{X} 11$ & $<---$ & Price & 1.000 & & & & .755 \\
\hline $\mathrm{X} 10$ & $<---$ & Price & .918 & .099 & 9.298 & $* * *$ & .803 \\
\hline X9 & $<---$ & Price & .676 & .083 & 8.115 & $* * *$ & .652 \\
\hline $\mathrm{X} 15$ & $<---$ & Prestige & 1.000 & & & & .777 \\
\hline $\mathrm{X} 14$ & $<---$ & Prestige & .908 & .087 & 10.481 & $* * *$ & .785 \\
\hline $\mathrm{X} 13$ & $<---$ & Prestige & .887 & .080 & 11.143 & $* * *$ & .817 \\
\hline X19 & $<---$ & Transaction & 1.000 & & & & .798 \\
\hline $\mathrm{X} 18$ & $<---$ & Transaction & 1.168 & .111 & 10.543 & $* * *$ & .815 \\
\hline $\mathrm{X} 17$ & $<---$ & Transaction & 1.228 & .116 & 10.583 & $* * *$ & .810 \\
\hline $\mathrm{X} 22$ & $<---$ & Hedonic & 1.000 & & & & .722 \\
\hline $\mathrm{X} 21$ & $<---$ & Hedonic & .953 & .115 & 8.253 & $* * *$ & .753 \\
\hline $\mathrm{X} 20$ & $<---$ & Hedonic & .927 & .110 & 8.413 & $* * *$ & .735 \\
\hline $\mathrm{X} 26$ & $<---$ & Quality & 1.000 & & & & .780 \\
\hline $\mathrm{X} 25$ & $<---$ & Quality & .960 & .105 & 9.126 & $* * *$ & .749 \\
\hline $\mathrm{X} 24$ & $<---$ & Quality & .897 & .101 & 8.848 & $* * *$ & .736 \\
\hline $\mathrm{X} 27$ & $<---$ & Quality & 1.014 & .106 & 9.614 & $* * *$ & .738 \\
\hline $\mathrm{X} 23$ & $<---$ & Hedonic & .865 & .112 & 7.685 & $* * *$ & .663 \\
\hline $\mathrm{X} 16$ & $<---$ & Prestige & .999 & .094 & 10.683 & $* * *$ & .760 \\
\hline $\mathrm{X} 12$ & $<---$ & Price & .800 & .103 & 7.755 & $* * *$ & .643 \\
\hline $\mathrm{X} 4$ & $<---$ & Self_Gratification & 1.019 & .103 & 9.938 & $* * *$ & .797 \\
\hline $\mathrm{X} 8$ & $<---$ & Aeshtetics & .709 & .091 & 7.789 & $* * *$ & .648 \\
\hline Y4 & $<---$ & Customer_Loyalty & 1.000 & & & & .739 \\
\hline Y5 & $<---$ & Customer_Loyalty & 1.229 & .110 & 11.174 & $* * *$ & .797 \\
\hline Y6 & $<---$ & Customer_Loyalty & 1.105 & .109 & 10.155 & $* * *$ & .726 \\
\hline Y1 & $<---$ & Customer_Satisfaction & 1.000 & & & & .714 \\
\hline $\mathrm{Y} 2$ & $<---$ & Customer_Satisfaction & .775 & .078 & 9.993 & $* * *$ & .724 \\
\hline $\mathrm{Y} 3$ & $<---$ & Customer_Satisfaction & .808 & .088 & 9.169 & $* * *$ & .719 \\
\hline
\end{tabular}

C.R. for each relationship between the variables tested is shown in table 4.1. These results show that of the 15 proposed hypotheses, there are 12 accepted hypotheses that have a value of C.R. above 2.00 


\subsection{Hypotheses Testing}

Table 4.4: Summary of Testing Results.

\begin{tabular}{|l|c|}
\hline Hypotheses & Analysis \\
\hline H1: Self Gratification has a significant effect on Customer Satisfaction & Accepted \\
\hline H2: Aeshtetics has a significant effect on Customer Satisfaction & Accepted \\
\hline H3: Price has a significant effect on Customer Satisfaction & Accepted \\
\hline H4: Prestige has a significant effect on Customer Satisfaction & Accepted \\
\hline H5: Transaction has a significant effect on Customer Satisfaction & Accepted \\
\hline H6: Hedonic has a significant effect on Customer Satisfaction & Accepted \\
\hline H7: Quality has a significant effect on Customer Satisfaction & Accepted \\
\hline H8: Self Gratification has a significant effect on Customer Loyalty & Rejected \\
\hline H9: Aeshtetics has a significant effect on Customer Loyalty & Accepted \\
\hline H10: Price has a significant effect on Customer Loyalty & Accepted \\
\hline H11: Prestige has a significant effect on Customer Loyalty & Accepted \\
\hline H12: Transaction has a significant effect on Customer Loyalty & Rejected \\
\hline H13: Hedonic has a significant effect on Customer Loyalty & Rejected \\
\hline H14: Quality has a significant effect on Customer Loyalty & Accepted \\
\hline H15: Customer Satisfaction has a significant effect on Customer Loyalty & Accepted \\
\hline
\end{tabular}

\subsection{Discussion}

\subsubsection{The effect of Self Gratification on Customer Satisfaction}

The first hypothesis shows that Self Gratification has a significant positive effect on Customer Satisfaction with a regression coefficient value of 0.170 with a C.R value of 2.142 which indicates that this hypothesis is accepted. This is because Hotel Vasa customers can relax while staying and can release stress because the atmosphere at Hotel Vasa is like a holiday atmosphere. Hotel Vasa also provides various kinds of facilities that customers do not usually do at home so that customers can carry out activities that are different from their daily routine.

\subsubsection{The effect of Aeshtetics on Customer Satisfaction}

The second hypothesis shows that Aesthetics has a significant positive effect on Customer Satisfaction with a regression coefficient value of 0.275 with a C.R value of 3.241 . This is because Hotel Vasa provides various kinds of furniture and places that are specially designed that aim to make customers feel that the atmosphere applied at Hotel Vasa is an aesthetic, beautiful, and elegant atmosphere. Hotel Vasa also makes a more modern design so that many people are interested in coming to Hotel Vasa because the atmosphere provided is an atmosphere that is elegant. The aesthetics created by the Vasa Hotel, directly or indirectly, have a positive impact.

\subsubsection{The effect of Price on Customer Satisfaction}

The third hypothesis shows that Price has a significant positive effect on Customer Satisfaction with a regression coefficient value of 0.225 with a value of C.R 2.637 which indicates that this hypothesis is accepted. This is because what Vasa Hotel provides is a price that is appropriate or commensurate with what customers get. The accommodation and dining places at Hotel Vasa are of good quality. For example, Hotel Vasa makes a restaurant called Chamas Restaurant where the restaurant is a restaurant with a concept from abroad that has never existed in the city of Surabaya before, namely the Brazillian Concept, but the price paid is commensurate. The facilities provided by Hotel Vasa are also very complete, such as Hotel Vasa providing 
an outdoor swimming pool with a beautiful view, the availability of Flex and Fit places for customers who want a Gym, provided a place for children's play, and also provided an Executive Loungue for customers who need a comfortable place. quieter. Through the facilities and accommodation available at the Vasa hotel, the price offered to guests to stay is considered commensurate.

\subsubsection{The effect of Prestige on Customer Satisfaction}

The fourth hypothesis shows that Prestige has a significant positive effect on Customer Satisfaction with a regression coefficient value of 0.175 with a C.R value of 2.074 which indicates that this hypothesis is accepted. This is because Hotel Vasa is one of the hotels that looks luxurious and prestigious in the city of Surabaya. The majority of customers feel that in addition to the service and quality provided by Hotel Vasa, the degree of customer identity when staying at Hotel Vasa will increase.

\subsubsection{The effect of Transaction on Customer Satisfaction}

The fifth hypothesis shows that the Transaction has a significant positive effect on Customer Satisfaction with a regression coefficient value of 0.327 with a value of C.R. 4,004 which indicates that this hypothesis is accepted. This is because customers at Hotel Vasa are customers who take advantage of various attractive offers such as discounts or promos. Customers feel that when staying at the Vasa Hotel with a discount or promo, it is a fortune for the customer because the Vasa Hotel is an elegant and expensive hotel in the city of Surabaya. Customers also feel the same way when staying at Vasa Hotel because the services provided by the Vasa Hotel are maximum and quality services. Customers of Hotel Vasa are predominantly aged 18 to 35 years who are influential because customers are happy with the existing promos.

\subsubsection{The effect of Hedonic on Customer Satisfaction}

The sixth hypothesis shows that hedonic has a significant positive effect on Customer Satisfaction with a regression coefficient value of 0.337 with a value of C.R. 3.949 which indicates that this hypothesis is accepted. This is because customers at Hotel Vasa are customers who are looking for pleasure by staying at a hotel because the atmosphere of Hotel Vasa is a pleasant and comfortable atmosphere. The atmosphere at the Vasa Hotel makes customers feel happy to spend time. Therefore the atmosphere of the Hotel Vasa causes the level of customer satisfaction to rise. Customers of Vasa Hotel are dominant in the age of 18 to 35 years, which means that at that age the customer understands and understands technology and can easily know about information on places to have fun.

\subsubsection{The effect of Quality on Customer Satisfaction}

The seventh hypothesis shows that Quality has a significant positive effect on Customer Satisfaction with a regression coefficient value of 0.297 with a value of C.R. 3.687 which indicates that this hypothesis is accepted. This is because Vasa Hotel provides the best quality services, for example, such as entertaining customers politely and friendly, customers are directed to the living room and served properly. Hotel Vasa also provides various types of rooms and facilities that are of high quality so that customers can experience the best quality from Hotel Vasa itself.

\subsubsection{The effect of Self Gratification on Customer Loyalty}

The eighth hypothesis shows that Self Gratification has a positive but not significant effect on Customer Loyalty with a regression coefficient value of 0.015 with a C.R value of 0.213 which indicates that this hypothesis is rejected. This is because customers feel there are still various ways to relax, release stress and forget about problems. In addition, customers feel that activities that are different from the daily routine of customers, not only can be done at Hotel Vasa but can also be done outside Vasa Hotel, but customers are 
satisfied with what customers enjoy when they are at Vasa Hotel.

\subsubsection{The effect of Aeshtetics on Customer Loyalty}

The ninth hypothesis shows that Aesthetics has a significant positive effect on customer loyalty with a regression coefficient value of 0.191 with a value of C.R 2.093 which indicates that this hypothesis is accepted. This is because the majority of guests who stay at Vasa Hotels feel that the appearance and atmosphere offered by Vasa Hotels looks elegant and comfortable to live in. This is also in accordance with the majority of millennial age respondents who really like to capture moments in an aesthetic place so that it can have a positive impact on the loyalty of guests who attend.

\subsubsection{The effect of Price on Customer Loyalty}

The tenth hypothesis shows that Price has a significant positive effect on Customer Loyalty with a regression coefficient value of 0.250 with a value of C.R 2.907 which indicates that this hypothesis is accepted. This is because Hotel Vasa provides a price that is commensurate with what Hotel Vasa provides. Customers feel satisfied what customers get such as service, food and drinks at the Hotel Vasa restaurant, classy rooms, lots of quality accommodation so that customers feel what customers pay for is acceptable.

\subsubsection{The effect of Prestige on Customer Loyalty}

The eleventh hypothesis shows that Prestige has a significant positive effect on Customer Loyalty with a regression coefficient value of 0.172 with a C.R value of 2.126 which indicates that this hypothesis is accepted. This is because the majority of respondents' ages are 18 to 35 years, where this age still really likes luxurious and prestigious places, and also respondents aged 18 to 35 years are respondents who are still happy to inform their status on social media, so with The luxury offered by Hotel Vasa makes respondents directly interested in coming or staying at Hotel Vasa.

\subsubsection{The effect of Transaction on Customer Loyalty}

The twelfth hypothesis shows that Transaction has a positive but not significant effect on Customer Loyalty with a regression coefficient value of 0.107 with a value of C.R 1.179 which indicates that this hypothesis is rejected. This is because customers feel that there are still other hotel options that can provide more attractive special offer prices so that it does not have a significant impact on the intention to stay back at Vasa Hotel, but customers are satisfied with what customers enjoy when they are at the very classy Vasa Hotel. in the Surabaya area. The Transaction variable cannot directly affect the Customer Loyalty variable but must go through the Customer Satisfaction variable first to form the Customer Loyalty variable because customers are satisfied with the service at Hotel Vasa, but the offers provided by Hotel Vasa can still be found elsewhere.

\subsubsection{The effect of Hedonic on Customer Loyalty}

The thirteenth hypothesis shows that Hedonic has a positive but not significant effect on Customer Loyalty with a regression coefficient value of 0.097 with a C.R value of 1.040 which indicates that this hypothesis is rejected. This is because customers feel they can find pleasure in other places. Customers feel that when they spend time having fun it is not only possible at the Vasa Hotel. Even so, customers are satisfied and feel happy with the atmosphere provided by the Vasa Hotel. The Hedonic variable cannot directly affect the Customer Loyalty variable but must first go through the Customer Satisfaction variable to form the Customer Loyalty variable. 


\subsubsection{The effect of Quality on Customer Loyalty}

The fourteenth hypothesis shows that Quality has a significant positive effect on Customer Loyalty with a regression coefficient value of 0.263 with a value of C.R 2.909 which indicates that this hypothesis is accepted. This is because all the things provided by Hotel Vasa such as services, facilities, and accommodation are of high quality and make customers feel satisfied so that from feeling satisfied, customers will automatically choose Vasa Hotel when customers are looking for a hotel to stay and also customers will automatically recommend Hotel Vasa to family or friends of customers.

\subsubsection{The effect of Customer Satsfaction on Customer Loyalty}

The fifteenth hypothesis shows that Customer Satisfaction has a significant positive effect on Customer Loyalty with a regression coefficient value of 0.356 with a C.R value of 2.115 which indicates that this hypothesis is accepted. This is because the majority of customers are satisfied with all the services and accommodations offered to guests staying at Hotel Vasa. This is in accordance with the majority of respondents aged 18 to 35 years who are respondents who are very concerned about the satisfaction of the services provided to them so as to create a sense of coming back to stay at the Vasa Hotel.

\section{Conclusion}

Based on the

\subsection{Managerial Implications}

Table 5.1: Managerial Implications

\begin{tabular}{|c|c|}
\hline Current Research & Managerial Implications \\
\hline $\begin{array}{l}\text { Self Gratification is one } \\
\text { element that has an influence } \\
\text { in the process of increasing } \\
\text { Customer Satisfaction and } \\
\text { Customer Loyalty }\end{array}$ & $\begin{array}{l}\text { - Hotel Vasa needs to improve the experience through bundling packages } \\
\text { with tours to tourist attractions } \\
\text { - Hotel Vasa needs to ensure the cleanliness of every room in the hotel in } \\
\text { order to create a comfortable impression for guests who stay } \\
\text { - Hotel Vasa needs to entertain guests who come with a welcome drink }\end{array}$ \\
\hline $\begin{array}{l}\text { Aesthetics is one of the } \\
\text { elements that has an } \\
\text { influence in the process of } \\
\text { increasing Customer } \\
\text { Satisfaction and Customer } \\
\text { Loyalty }\end{array}$ & $\begin{array}{l}\text { - Hotel Vasa needs to do greening around the hotel so that it creates a } \\
\text { comfortable and cool impression } \\
\text { - Management needs to pay attention to the lighting used in every room of } \\
\text { the hotel } \\
\text { - Hotel Vasa must regularly pay attention to the cleanliness of the hotel } \\
\text { building that is visible from the outside }\end{array}$ \\
\hline $\begin{array}{l}\text { Price is one element that has } \\
\text { an influence in the process of } \\
\text { increasing Customer } \\
\text { Satisfaction and Customer } \\
\text { Loyalty }\end{array}$ & $\begin{array}{l}\text { - Hotel Vasa needs to maintain the accommodation provided to guests who } \\
\text { stay, such as a guest pick-up facility at the airport. } \\
\text { - Management can maintain the price offered } \\
\text { - Hotel Vasa needs to provide several promos that attract the attention of } \\
\text { potential guests at Vasa hotels }\end{array}$ \\
\hline $\begin{array}{l}\text { Prestige is one element that } \\
\text { has an influence in the } \\
\text { process of increasing } \\
\text { Customer Satisfaction and } \\
\text { Customer Loyalty }\end{array}$ & $\begin{array}{l}\text { - The management needs to maintain the good image of the Vasa hotel } \\
\text { - Vasa hotels can provide souvenirs to every guest who stays to create a } \\
\text { prestigious and classy impression for guests staying at Vasa hotels. }\end{array}$ \\
\hline
\end{tabular}




\begin{tabular}{|c|c|}
\hline $\begin{array}{l}\text { Transaction is one element } \\
\text { that has an influence in the } \\
\text { process of increasing } \\
\text { Customer Satisfaction and } \\
\text { Customer Loyalty }\end{array}$ & $\begin{array}{l}\text { - Hotel Vasa needs to regularly collaborate with third party applications } \\
\text { such as Traveloka, tiket.com or Agoda } \\
\text { - Management can also make lodging packages such as New Year's } \\
\text { specials } \\
\text { - Hotel Vasa needs to make such a fireworks display when there are } \\
\text { certain events }\end{array}$ \\
\hline $\begin{array}{l}\text { Hedonic is one element that } \\
\text { has an influence in the } \\
\text { process of increasing } \\
\text { Customer Satisfaction and } \\
\text { Customer Loyalty }\end{array}$ & $\begin{array}{l}\text { - Management can add free wine accommodation to guests staying in } \\
\text { executive and suite rooms so that they can provide an interesting } \\
\text { experience } \\
\text { - Vasa hotels need to maintain friendly service to guests }\end{array}$ \\
\hline $\begin{array}{l}\text { Quality is one element that } \\
\text { has an influence in the } \\
\text { process of increasing } \\
\text { Customer Satisfaction and } \\
\text { Customer Loyalty }\end{array}$ & $\begin{array}{l}\text { - The management needs to maintain the best quality of service to guests } \\
\text { who stay through tranning on a regular basis to every servant who works } \\
\text { in Vasa hotels. } \\
\text { - The management can give a questionnaire to each guest who is present to } \\
\text { find out what deficiencies need to be fixed by Vasa hotel services }\end{array}$ \\
\hline $\begin{array}{l}\text { Customer Satisfaction is one } \\
\text { element that has an influence } \\
\text { in the process of increasing } \\
\text { Customer Loyalty }\end{array}$ & $\begin{array}{l}\text { - The hotel should strive to improve hotel services through the addition of } \\
\text { facilities that are not available to hotel hotels so that they can be of added } \\
\text { value to Vasa hotels. }\end{array}$ \\
\hline
\end{tabular}

Based on the results of this study, the main recommendations made for the object of this research are, Vasa Hotel needs to regularly collaborate with third party applications such as Traveloka, tiket.com or Agoda, so that it can attract the public's interest to be able to enjoy the experience at Vasa hotels with offers. special price. This recommendation is a recommendation taken from the Transaction variable because the Transaction variable is the variable with the greatest influence.

\subsection{Recommendation}

Looking at the results of existing research where there are still many limitations to the research conducted by the author, the recommendations that can be submitted by the author are as follows:

- Seeing the limitations regarding the object of research that only takes respondents, namely guests who stay at the Vasa Hotel in Surabaya, it is hoped that the next research using the same or modified model can be applied to different objects to get more general results on the factors that affect Customer Loyalty.

- Further research is expected to complement the existing variables in this research so that it can further enhance the understanding of the factors that influence Customer Loyalty, including Brand Trust, Location, Percive Value, Service Quality, Athmosphere, Word of Mouth, Sociality., and Sociality.

- Further research can be developed by linking the factors that influence customer loyalty based on education level and income. Future research could also expand the scope of respondents to be researched, or carry out their research in a different area from the current research. So that further research carried out provides a broad picture of Customer Loyalty.

- In addition, it is hoped that not only using the Structural Equational Model (SEM) but also using Lisrel or SPSS software in future studies. 


\section{References}

Al-Sabbahy, H. Z., Ekinci, Y., \& Riley, M. (2014). An investigation of perceived value dimensions: Implications for hospitality research. Journal of Travel Research, 42(3), 226-234.

Chahal, H., \& Kumari, N. (2011). Consumer perceived value and consumer loyalty in the healthcare sector. Journal of Relationship Marketing, 10(2), 88-112.

Chepchirchir, J., \& Leting, M. (2015). Effects of brand quality, brand prestige on brand purchase intention of mobile phone brands: Empirical assessment from Kenya.

Das, G. (2013). The effect of pleasure and arousal on satisfaction and word-of-mouth: an empirical study of the Indian banking sector. Vikalpa, 38(2), 95-104.

Davis, L., Peyrefitte, J., \& Hodges, N. (2015). From motivation to store choice: Exploring Northwest Chinese consumers' shopping behavior.

Dubois, B., \& Czellar, S. (2014). Prestige brands or luxury brands? An exploratory inquiry on consumer perceptions.

Erdoğmuş, İ., \& Büdeyri - Turan, I. (2014). The role of personality congruence, perceived quality and prestige on ready - to - wear brand loyalty. Journal of Fashion Marketing and Management: An International Journal.

Goetsch, D. L., \& Davis, S. (2014). Introduction to Total Quality: Quality. Productivity, Competitiveness, New Jersey: Prenticehall Inc.

Goetsch, D. L., \& Davis, S. B. (2014). Quality management for organizational excellence. Upper Saddle River, NJ: pearson.

Grewal, D., Monroe, K. B., \& Krishnan, R. (2014). The effects of price-comparison advertising on buyers' perceptions of acquisition value, transaction value, and behavioral intentions. Journal of marketing, 62(2), 46-59.

Ha, Y., \& Im, H. (2012). Role of web site design quality in satisfaction and word of mouth generation. Journal of Service Management.

Hanzaee, K. H., \& Taghipourian, M. J. (2015). The effects of brand credibility and prestige on consumers purchase intention in low and high product involvement. Journal of Basic and Applied Scientific Research, 2(2), 1281-1291.

Hwang, J., \& Han, H. (2014). Examining strategies for maximizing and utilizing brand prestige in the luxury cruise industry. Tourism Management, 40, 244-259.

Jeon, S. (2015). Exploring online auction behaviors and motivations. Journal of Family and Consumer Sciences, 100(2), 31.

Jin, N., Line, N. D., \& Merkebu, J. (2016). The impact of brand prestige on trust, perceived risk, satisfaction, and loyalty in upscale restaurants. Journal of Hospitality Marketing \& Management, 25(5), 523-546.

Jung, H. S., \& Yoon, H. H. (2010). The effects of servicescapes in Korean restaurants on customers' experiential value, pleasure feeling and customer satisfaction. Journal of the Korean Society of Food Culture, 25(1), 36-46. 
Kandampully J., Juwaheerm T.D. \& Hu, H.H (2015). The influence of a hotel firm's quality of service and image and its effect on tourism customer loyalty. International Journal of Hospitality \& Tourism Administration. 12(1), 21-42.

Kivetz, R., \& Zheng, Y. (2016). Determinants of justification and self-control. Journal of Experimental Psychology: General, 135(4), 572.

Kotler, P., \& Armstrong, G. (2015). Principles of marketing. Pearson education.

Kotler, P., \& Keller, K. L. (2016). Marketing management (15th global ed.). England: Pearson.

Kotler, Phillip dan Kevin Lane Keller.(2016). Manajemen Pemasaran edisi 12 Jilid 1 \& 2.Jakarta: PT. Indeks.

Lai, F., Li, X., \& Lai, V. S. (2013). Transaction - specific investments, relational norms, and ERP customer satisfaction: a mediation analysis. Decision Sciences, 44(4), 679-711.

Lee, C. K., Yoon, Y. S., \& Lee, S. K. (2017). Investigating the relationships among perceived value, satisfaction, and recommendations: The case of the Korean DMZ. Tourism management, 28(1), $204-$ 214.

Lupiyoadi, R., \& Hamdani, A. (2011). Manajemen Pemasaran Jasa. jakarta: Salemba Empat.

Moslehpour, M., \& Huyen, N. L. (2014). The influence of perceived brand quality and perceived brand prestige on purchase likelihood of iPhone and HTC mobile phone in Taiwan. Research in Business and Management, 1(1), 62-77.

Paramita, Adiska O., Zainul Arifin, dan Sunarti. 2014. Pengaruh Nilai Belanja Hedonis Terhadap Pembelian Impulsif Pada Toko Online Dengan Emosi Positif Sebagai Variabel Perantara. Jurnal Administrasi Bisnis (JAB) Vol.8 No.2.Retrieved from Universitas Brawijaya.

Parasuraman, A., \& Grewal, D. (2016). The impact of technology on the quality-value-loyalty chain: a research agenda. Journal of the academy of marketing science, 28(1), 168-174.

Petrick, J. F., \& Backman, S. J. (2015). An examination of the construct of perceived value for the prediction of golf travelers' intentions to revisit. Journal of travel research, 41(1), 38-45.

Shadab, R. (2012). Effects of ethical sales behavior considered through transaction cost theory: To whom is the customer loyal?. Oman Chapter of Arabian Journal of Business and Management Review, 34(974), $1-8$.

Sweeney, J. C., \& Soutar, G. N. (2014). Consumer perceived value: The development of a multiple item scale. Journal of retailing, 77(2), 203-220.

Xia, L., \& Monroe, K. B. (2015). Is a good deal always fair? Examining the concepts of transaction value and price fairness. Journal of Economic Psychology, 31(6), 884-894.

Xia, L., \& Monroe, K. B. (2016). Is a good deal always fair? Examining the concepts of transaction value and price fairness. Journal of Economic Psychology, 31(6), 884-894

Zayerkabeh, S., Albabayi, A., \& Abdoli, M. (2012). Studying the effect of brand credibility and brand prestige on brand loyalty. Australian Journal of Basic and Applied Sciences, 6(8), 160-166. 


\section{Appendix}

\section{Self-Gratification}

1. I feel when staying at the Hotel Vasa really feels like running away from the pressures of life

2. I feel that during my stay at Hotel Vasa, I can forget about my problems

3. I feel when staying at Hotel Vasa it helps me release stress and relax

4. I feel staying at the Vasa Hotel is a way to do something different from my daily routine

\section{Aesthetics}

1. I feel that the outer appearance of the Hotel Vasa is elegant

2. I find the Vasa Hotel furnishings aesthetically appealing

3. I feel the view from Hotel Vasa is very beautiful

4. I feel that the interior of the Hotel Vasa is artistically designed and decorated

\section{Price}

1. In my opinion, Hotel Vasa provides great accommodation that is worth the price

2. In my opinion, the food and drinks served at Hotel Vasa are worth the price

3. In my opinion, Hotel Vasa offers great services like car rental, spa, etc. which are well worth the price

4. In my opinion, in general, the Vasa Hotel prices are acceptable

\section{Prestige}

1. I feel that staying at the Hotel Vasa is considered prestigious

2. I consider staying at the Vasa Hotel to be a status symbol

3. I feel that staying at the Vasa Hotel is in accordance with my social status

4. I feel proud when I stay at Hotel Vasa

\section{Transaction}

1. I feel very smart when I get special prices, offers, or discounts at Vasa Hotels

2. I enjoy the thrill of discovering that expensive services room at Hotel Vasa are really a special rate

3. I feel that my staying experience at Hotel Vasa was a fortune when I found several offers such as special prices, offers, discounts, and others

\section{Hedonic}

1. In my opinion, the atmosphere of the Hotel Vasa keeps me happy

2. I feel happy to be at Hotel Vasa

3. I feel happy during my stay at Hotel Vasa because of the atmosphere

4. I felt the time spent at Hotel Vasa was really enjoyable

Quality

1. In my opinion, Hotel Vasa provides the highest quality service

2. In my opinion, the quality of the Vasa Hotel's services is very consistent

3. In my opinion, Hotel Vasa's services are considered very reliable

4. In my opinion, Hotel Vasa is considered a high quality Hotel

\section{Customer Satisfaction}

1. In my opinion, the experience of staying at Hotel Vasa makes me satisfied

2. In my opinion, my choice to stay at Hotel Vasa was a wise choice

3. In my opinion, overall I am satisfied with the Hotel.

\section{Customer Loyalty}

1. I feel there is a big possibility to return to Hotel Vasa in the future if the opportunity arises

2. I feel I will continue to stay at Hotel Vasa in the future

3. I will recommend Hotel Vasa to my friends 